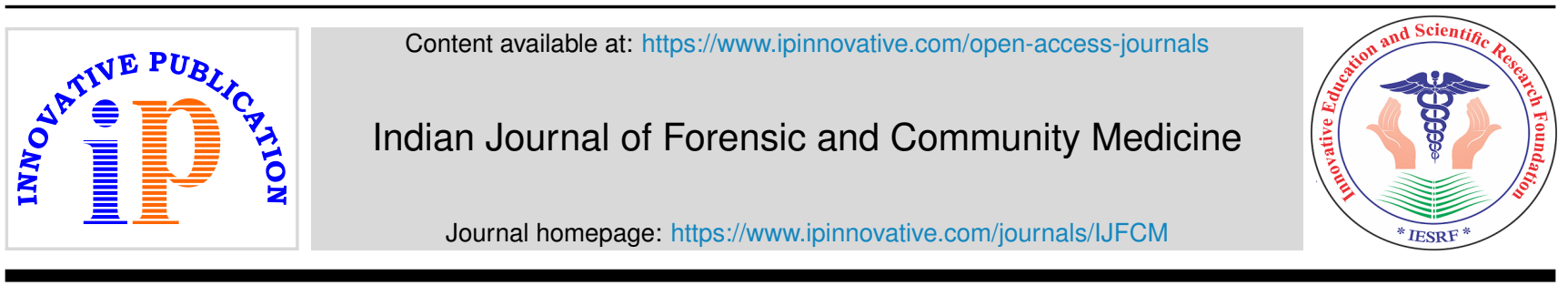

Original Research Article

\title{
Pattern of flame burn injury in Dibrugarh district of Assam: An autopsy based analysis
}

\author{
Swapan Debbarma ${ }^{1, *}$ \\ ${ }^{1}$ Dept. of Forensic Medicine and Toxicology, All India Institute of Medical Sciences, Rishikesh, Uttarakhand, India
}

\section{A R T I C L E I N F O}

\section{Article history:}

Received 24-11-2020

Accepted 02-12-2020

Available online 08-01-2021

\section{Keywords:}

Burn

Flame

Fire

Kerosene

Accident

Suicide

Hypovolemic shock

\begin{abstract}
A B S T R A C T
Background: Burn injuries are the second major cause of trauma-related deaths only exceeded by motor vehicular accidents, both in the developing and developed world. Burn due to flame or fire is common in this region.

Aims: To find out epidemiological patterns and cause of death in the flame burn as data on it is not available even though the most common cause of burn in this region.

Settings and Design: This cross-sectional observational study was carried out at the Department of Forensic Medicine, Assam Medical College, Dibrugarh from 1st July 2014 to 30th June 2015.

Methods and Materials: A total of 224 cases died of flame burn brought for autopsy were taken for study. A thorough post-mortem examination was done on every case following standard procedure. Data were recorded in the proforma especially prepared for this purpose.

Results: Out of 1436 medico-legal deaths, $224(15.60 \%)$ was due to flame burn. The majority of victims were female $186(83.03 \%)$, married, and belong to 21-30 years of age group. Victims were mostly from rural areas, unemployed, and literates. Kitchen $129(57.60 \%)$ was the main place of occurrence. The majority suffered more than $80 \%$ burns of TBSA and died within 24 hours 92 (41.07\%). The hypovolemic shock was the most common cause of death.

Conclusions: Until the economic condition is improved and lifestyle changes among the people, the firerelated problem must rise in countries like India.

Key Messages: Young age groups and unemployed were most among victims. Burn incidents decrease with increasing education level. Economic improvement and change of lifestyles will help in reducing burn-related problems.

(C) This is an open access article distributed under the terms of the Creative Commons Attribution License (https://creativecommons.org/licenses/by/4.0/) which permits unrestricted use, distribution, and reproduction in any medium, provided the original author and source are credited.
\end{abstract}

\section{Introduction}

Burn injuries are the second major cause of trauma-related deaths only exceeded by motor vehicular accidents, both in the developing and developed world. ${ }^{1}$ Fire or flame is a common cause of burn in this region. Like other trauma, burn causes significant morbidity and mortality all over the world. As per the report of the Indian National Crime Records Bureau of 2014, out of 316828 unnatural accidental deaths, $19513(4.3 \%)$ were due to fire accidents. ${ }^{2}$ This study was conducted to find out epidemiological patterns and

\footnotetext{
* Corresponding author.

E-mail address: sipingdb@gmail.com (S. Debbarma).
}

cause of death in the flame burn as data on it is not available even though the most common cause of burn in this region.

\section{Materials and Methods}

A total of 224 cases of flame burns were taken from the medico-legal autopsies performed in the Department of Forensic Medicine, Assam Medical College, Dibrugarh during the period from $1^{\text {st }}$ July 2014 to $30^{\text {th }}$ June 2015 out of 1436 medico-legal autopsies. The various detailed data of all cases were collected from police inquest papers or investigating officers, hospital papers, family members, friends available, persons present at the time of incidence, 
or accompanying the victim. A thorough post-mortem examination was done on every case and total body surface area (TBSA) was calculated according to Wallace's rule of nine. Data of all 224 cases were recorded in the prevalidated proforma especially prepared for this purpose. These were carefully compiled, tabulated, and analyzed using Microsoft excel.

\section{Observations and Results}

Out of a total of 1436 autopsies, 224 cases were death due to flame burns which are $15.60 \%$ of the total.

\subsection{Age-sex distribution}

[Table 1 ] The highest number of cases observed in the 21-30 years of age group and 11-40 years of age group constitutes $188(83.94 \%)$ of cases. Considering the sex, 186 cases were female and 38 were male which makes the male: female ratio 1:4.9.

\subsection{Marital status}

[Table 2] Most of the victims were married [182; 81.25\%] and widows were the least numbers of total cases. Out of the married cases, $153(68.30 \%)$ were females. Male cases were significantly high in victims married for more than 7 years. Out of the married female $6(3.92 \%)$ cases were found pregnant in the present study.

\subsection{Religion}

The majority cases 211 (94.20\%) were Hindu, then Muslim $9(4.01 \%)$, followed by Christian $3(1.34 \%)$ and Sikh 1 $(0.45 \%)$ respectively. Muslim cases were female.

\subsection{Locality}

It was observed that rural cases [186; $83.03 \%$ ] both in males and females outnumbered the semi-urban [20;8.93] and urban [18; 8.04] among victims.

\subsection{Occupation}

[Table 3] The highest cases were unemployed [129; $57.59 \%$ ] of which housewife constitutes the largest group with $108(48.21 \%)$ cases of the total, followed by daily wager [61; 27.23\%], and least semi-government employee with $1(0.45 \%)$ case. Children, students included in other categories of unemployed persons.

\subsection{Education}

Illiterate [61;27.23\%] and Primary level [61; 27.23\%] constitutes the highest cases, and numbers of cases were declining with an increase in the education level.[Table 4]

\subsection{Place of incident}

Maximum place of occurrence is in the kitchen with 129 $(57.60 \%)$ cases. Inside house $[198 ; 88.40 \%]$ is the place where incident mostly occurs. [Table 5]

\subsection{Seasonal distribution}

Highest $71(31.70 \%)$ cases observed in winter (NovemberFebruary), followed by $67(29.91 \%)$ in Rainy (JuneSeptember), 64 (28.57\%) in Spring (March-May), and least $22(9.82 \%)$ cases in autumn (October). The season division is as per the Assam state weather calendar.

\subsection{Body surface area}

Maximum of $98(43.76 \%)$ cases had burn injuries involving $>80 \%$ of TBSA and only $20(8.93 \%)$ cases were found with $<40 \%$ of TBSA. No case was found with burns involving $<10 \%$ of TBSA. (Figure 1)

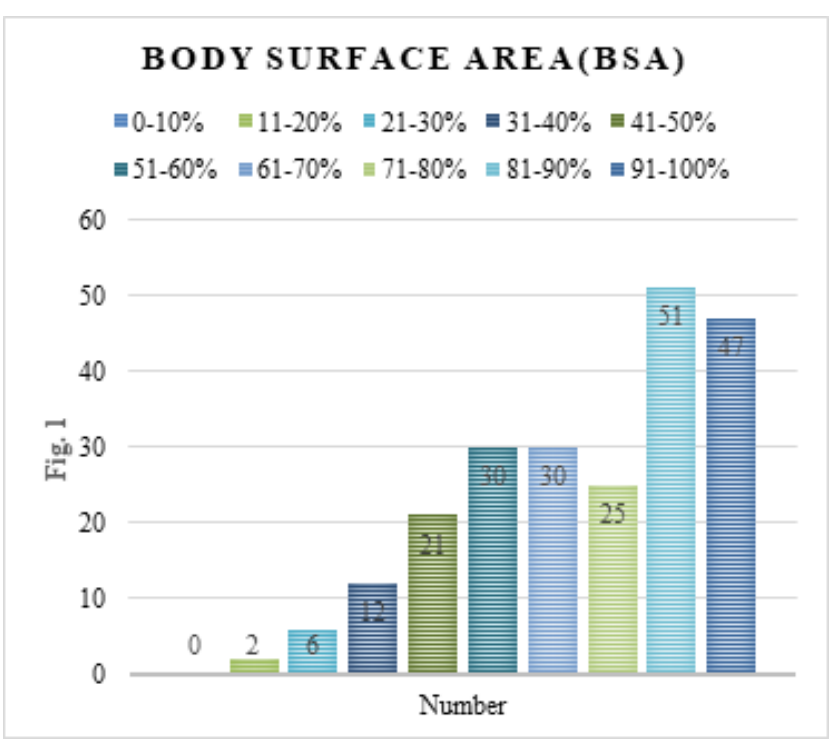

Fig. 1: Body surface area

\subsection{Survival period}

[Table 6] It was observed that most of the victims [44; $19.64 \%$ ] survived 8-14 days, and at least 10 (4.46\%) cases survived 4-6 hours of duration. Altogether, the highest 92 $(41.07 \%)$ cases died within 24 hours period. Comparison between TBSA involvement and Survival period shown in Table 7.

\subsection{Cause of death}

Most of the cases $[107 ; 47.76 \%$ ] died due to hypovolemic shock, and septicemic shock was the second most common cause of death with 99 (44.20\%) cases.(Figure 2) 
Table 1: Age-sex distribution

\begin{tabular}{|c|c|c|c|c|}
\hline Age (in years) & Male & Female & Total & Percentage \\
\hline $0-10$ & 2 & 1 & 3 & 1.34 \\
\hline $11-20$ & 4 & 37 & 41 & 18.30 \\
\hline $21-30$ & 9 & 91 & 100 & 44.64 \\
\hline $31-40$ & 14 & 33 & 47 & 21.00 \\
\hline $41-50$ & 3 & 15 & 18 & 8.03 \\
\hline $51-60$ & 3 & 6 & 9 & 4.01 \\
\hline $61-70$ & 3 & 3 & 6 & 2.68 \\
\hline Sum & 38 & 186 & 224 & 100 \\
\hline
\end{tabular}

Table 2: Marital status and time since marriage

\begin{tabular}{|c|c|c|c|c|c|c|}
\hline Marital status & \multicolumn{2}{|c|}{ Male } & \multicolumn{2}{|c|}{ Female } & Total & Percentage \\
\hline Widow & \multicolumn{2}{|c|}{0} & \multicolumn{2}{|c|}{8} & 8 & 3.57 \\
\hline Unmarried & \multicolumn{2}{|c|}{9} & \multicolumn{2}{|c|}{25} & 34 & 15.18 \\
\hline Married & $\begin{array}{l}<7 \text { years } \\
>7 \text { years }\end{array}$ & $\begin{array}{c}7 \\
22\end{array}$ & $\begin{array}{l}<7 \text { years } \\
>7 \text { years }\end{array}$ & $\begin{array}{l}74 \\
79\end{array}$ & 182 & 81.25 \\
\hline Sum & \multicolumn{2}{|c|}{38} & \multicolumn{2}{|c|}{186} & 224 & 100 \\
\hline
\end{tabular}

Table 3: Occupation of victims

\begin{tabular}{|c|c|c|c|}
\hline Occupation & & Number & Percentage \\
\hline \multirow{2}{*}{ Unemployed } & Housewife & 108 & 48.21 \\
\hline & Others & 21 & 9.38 \\
\hline Daily Wager & & 61 & 27.23 \\
\hline Farmer & & 2 & 0.89 \\
\hline Business & & 6 & 2.68 \\
\hline Self-employee & & 3 & 1.34 \\
\hline Private employee & & 14 & 6.25 \\
\hline Semi-Govt. employee & & 1 & 0.45 \\
\hline Govt. employee & & 8 & 3.57 \\
\hline Sum & & 224 & 100 \\
\hline
\end{tabular}

Table 4: Education status

\begin{tabular}{lccc}
\hline Education & Male & Female & Percentage \\
Illiterate & $11(4.91)$ & $50(22.31)$ & 27.23 \\
Primary & $11(4.91)$ & $50(22.31)$ & 27.23 \\
Middle + High school & $11(4.91)$ & $49(21.87)$ & 26.79 \\
Higher secondary & $2(0.89)$ & $23(10.27)$ & 11.16 \\
Undergraduate & $2(0.89)$ & $8(3.57)$ & 4.46 \\
Graduate & $1(0.45)$ & $5(2.23)$ & 2.68 \\
Post-graduate & & $1(0.45)$ & 0.45 \\
Sum & 16.97 & 83.03 & 100 \\
\hline
\end{tabular}

Table 5: Place of incident

\begin{tabular}{|c|c|c|c|c|c|}
\hline \multicolumn{2}{|c|}{ Place of Incident } & Male & Female & Number & Percentage \\
\hline \multirow{2}{*}{ Inside House } & Kitchen & 10 & 119 & 129 & 57.60 \\
\hline & Other room & 19 & 50 & 69 & 30.80 \\
\hline \multicolumn{2}{|l|}{ Outside house } & 9 & 17 & 26 & 11.60 \\
\hline \multicolumn{2}{|l|}{ Sum } & 38 & 186 & 224 & 100 \\
\hline
\end{tabular}


Table 6: Survival period

\begin{tabular}{lcc}
\hline Survival Period & Number & Percentage \\
0-3hours & 14 & 6.25 \\
4-6hours & 10 & 4.46 \\
7-12hours & 29 & 12.95 \\
13-24hours & 39 & 17.41 \\
2-3days & 23 & 10.27 \\
4-7days & 39 & 17.41 \\
8-14days & 44 & 19.64 \\
15days-1month & 15 & 6.70 \\
>1month & 11 & 4.91 \\
Sum & 224 & 100 \\
\hline
\end{tabular}

Table 7: TBSA involvement and Survival period comparison

\begin{tabular}{|c|c|c|c|c|c|c|c|c|c|c|c|}
\hline $\begin{array}{l}\text { Survival } \\
\text { period }\end{array}$ & $\begin{array}{c}0- \\
10 \%\end{array}$ & $11-20 \%$ & $\begin{array}{l}21- \\
30 \%\end{array}$ & $\begin{array}{c}31- \\
40 \%\end{array}$ & $41-50 \%$ & $\begin{array}{l}51- \\
60 \%\end{array}$ & $61-70 \%$ & $\begin{array}{l}71- \\
80 \%\end{array}$ & $81-90 \%$ & $\begin{array}{c}91- \\
100 \%\end{array}$ & Total \\
\hline $0-3$ hours & 0 & 0 & 1 & 0 & 0 & 0 & 1 & 1 & 5 & 6 & 14 \\
\hline 4-6 hours & 0 & 0 & 0 & 0 & 0 & 0 & 1 & 0 & 0 & 9 & 10 \\
\hline $\begin{array}{l}7-12 \\
\text { hours }\end{array}$ & 0 & 0 & 0 & 0 & 1 & 0 & 3 & 3 & 5 & 17 & 29 \\
\hline $\begin{array}{l}13-24 \\
\text { hours }\end{array}$ & 0 & 0 & 1 & 1 & 3 & 4 & 7 & 4 & 13 & 6 & 39 \\
\hline 2-3 days & 0 & 2 & 1 & 1 & 2 & 3 & 2 & 1 & 7 & 4 & 23 \\
\hline 4-7 days & 0 & 0 & 0 & 0 & 4 & 12 & 7 & 6 & 7 & 3 & 39 \\
\hline 8-14 days & 0 & 0 & 1 & 5 & 7 & 6 & 5 & 7 & 11 & 2 & 44 \\
\hline $\begin{array}{l}15 \text { days- } 1 \\
\text { month }\end{array}$ & 0 & 0 & 0 & 1 & 2 & 4 & 4 & 1 & 3 & 0 & 15 \\
\hline$>1$ month & 0 & 0 & 2 & 4 & 2 & 1 & 0 & 2 & 0 & 0 & 11 \\
\hline Sum & 0 & 2 & 6 & 12 & 21 & 30 & 30 & 25 & 51 & 47 & 224 \\
\hline
\end{tabular}

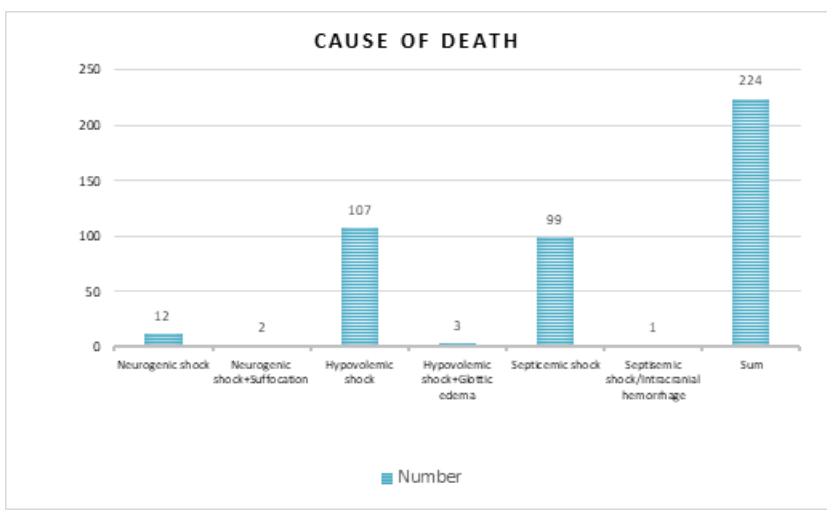

Fig. 2: Cause of Death

\section{Discussion}

Out of the total 1436 autopsies, 224 (15.60\%) cases died from flame burn injuries. Previous studies reported $16.70 \%,^{3}$ and $19.4 \%{ }^{4}$ cases died of burn which is comparable with present observation.

In this study, 11-40 years of age group constitutes a maximum of cases [188; 83.94\%] with a female predominance (male: female ratio 1:4.9). Other studies in India have reported similar findings with maximum cases between 11-40 years of age group and female predominance. ${ }^{3,5-10}$ It is because people of this age group are actively involved in both indoor and outdoor work. Family disharmony and stress also gives them social trauma and propel them to commit suicide. On contrary, in western countries, children and the elderly, and males were more in burn injuries. ${ }^{11,12}$ The early marriage in females and involvement in kitchen work even at an early age in India make them susceptible to an accident. Bride burn for the sake of dowry is also a reason women suffer burn. The present study shows maximum cases were married females $[153 ; 68.30 \%]$ of which $74(48.36 \%)$ cases were within 7 years of active marriage life. Several other studies also have shown married female predominance. ${ }^{3,10,13-16}$

Most of the victims were from the rural area [186; $83.04 \%]$ and Hindu by religion $[211 ; 94.20 \%]$ in this study, and consistent with other studies. ${ }^{13,17-19}$ This may be due to low income, lifestyle, and being Hindu majority area. A study also showed more in urban than the rural area and those urban migratory people who belong to poor socio-economic categories still use stoves for daily cooking work. ${ }^{8}$

Though overall literates are more than illiterates as per education, maximum victims were educated up to primary level only which constitute $61(27.23 \%)$ ] cases out of total 
victims. A decline in the number of cases with an increase in education level observed. Many studies also observed more in literates, ${ }^{10,18,20,21}$ and others in illiterates. ${ }^{13,14,22-25}$ It might be due fact that education improves the confidence of a person and economic status increases awareness and safety in handling inflammable substances. In low economic class Chula and Kerosene stoves for cooking, and use of Lamp, Chaki, Dia, Candle for light in absence of electricity increase the fire-related incidence more commonly as these materials are cheaper and easily available which fit their budgets.

The majority of the victims were housewives followed by daily wagers. Other studies also found housewives were highest among victims. ${ }^{8,20,22}$ Burn injuries occurred mostly in the kitchen, $9,18,20$ that is similar to this study. Overall inside house occurrence and unemployed are highest. This high incidence in housewives may be due to regular exposure to fire during cooking in the kitchen, inexperience in handling the unsafe cooking appliances, and too much pressure in work leading to accidents. The loose clothing like saree used by females in India and synthetic or mixed fabrics used by the poor also make them susceptible. Bonfire and open Chula are made for warming and cooking in winter increases the risk of fire accidents. The kitchen is the place where inflammable substances like kerosene and match sticks are stored and easily available to use for selfimmolation.

Burn injuries $>80 \%$ of TBSA comprises the highest victims in the present study. Other studies also have similar, 6,7,16 and different observations. ${ }^{5,26,27}$ Grossly though with a decrease in the involvement of TBSA, the period of survival increases but that didn't hold in all cases. Some cases with lesser TBSA involvement died early than those with higher. It implies that the period of survival or fatality of burn injuries depends on various factors other than the extent of the burn. Thus interpretation from the data is that chances of survival increased when burns involvement is less than $30 \%$ of total body surface area in this area.

Victims died most within 24 hours after the incident [92; 41.07\%]. Many studies observed similar results, $6,26,27$ and others found the majority died between 1-7 days after the incident. ${ }^{3,5,7}$ Most of the death occurred due to shock, out of which the majority were from hypovolemic shock. Shock also observed as a major cause of death in existing studies ${ }^{6,28}$ and other observed septicemia or septicemic shock. ${ }^{5,15,16,18,26}$

\section{Conclusion}

Burn incidents are seen more prevalent among women, unemployed, less educated, and in the kitchen. The low literacy rate and socio-economic status of the people are the major causes of accidental burns. These again lead to family disharmony, increases stress, and propel them to do suicide by burning. Schemes like the distribution of safe cooking appliances and awareness programs regarding the safe handling of fire-related appliances by the government will be a great help. Women should be given equal status in society. Women empowerment gives economic freedom, independent life, and helps economic upliftment to their family. As the fire-related injury is a major problem in India, till the economic condition is improved and lifestyle changes, the fire-related problem must rise. Psychiatric consultation should be available for tackling mental distress that usually develops due to day to day life experiences which is also a propelling factor for suicide.

\section{Source of Funding}

None.

\section{Conflict of Interest}

The authors declare no conflict of interest.

\section{References}

1. Goel A, Shrivastava P. Post-burn scars and scar contractures. Indian J Plast Surg. 2010;43(3):63-71. 001:104103/0प/(0-(1358.70/24

2. National Crime Records Bureau. Accidental Deaths and Suicides in India-2014. Ministry of Home Affairs. New Delhi: Government of India; 2014.

3. Gonnade U, Farooqui JM. Retrospective analysis of death due to burns in rural region. J Forensic Med Sci Law. 2013;22(2).

4. Kumar V, Mohanty MK, Kanth S. Fatal burns in Manipal area: A 10year study. J Forensic Legal Med. 2007;14(1):3-6. d01:10.1016/].jctm.2005.09.002

5. Sharma BR, Harish D, Sharma A, Sharma S, Singh H. Accidental Fatal burns in Indian Kitchens: Are they really accidental? J Indian Acad Forensic Med. 2006;28(1):14-7.

6. Memchoubi, Nabachandra H. A Study of Burn Death in Imphal. $J$ Indian Acad Forensic Med. 2007;29(4):131-4.

7. Zanjad NP, Godbole HV. Study of Fatal Burn Cases in Medico- Legal Autopsies. J Indian Acad Forensic Med. 2007;29(3):42-9.

8. Chawla R, Chanana A, Rai H, Aggarwal AD, Singh H, Sharma G. A Two-year Burns Fatality Study. J Indian Acad Forensic Med. 2010;32(4):292-7.

9. Bansude ME, Parchake MB, Kachare RV, Dode CR. Accidental Burns Death in Southern Marathwada Region. J Indian Acad Forensic Med. 2012;34(3):223-5.

10. Patel TC, Parmar AP, Bhagora L, Bhagora RV, Shah JP, Parmar VN. Epidemiological Study of Fatal Burn Cases Brought For Postmortem Examination at Mortuary of Sir Takhtsinhji General Hospital, Bhavnagar. Int J Res Med. 2015;4(1):113-6.

11. Anderson BA. Fire deaths in the Glasgow area. Med Sci Law. 1981;21(3):175-83.

12. Pegg SP. Burn epidemiology in the Brisbane and Queensland area. Burns. 2005;31(1):S27-S31. d01:10.1016/j.burns.2004.10.004.

13. Naik RS, Anjankar AJ, Sharma BR. Epidemiology of burnt females. Antiseptic. 1991;88(10):570-2.

14. Haralkar SJ, Tapare VS, Rayate MV. Study of socio-demographic profile of burn cases admitted in Shri Chhatrapati Shivaji Maharaj General Hospital, Solapur. Natl J Community Med. 2011;2(1):19-23.

15. Lal S, Shrivastava GP, Singh S, Yadav GK, Bain J, Gupta R. Mortality pattern of burn patients admitted in S. G. M. Hospital Rewa: A teaching institute of central India. J Sci Soc. 2012;39(3):130-5.

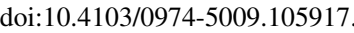

16. Karaddi S, Mugadlimath A, Babladi P. Study of deaths due to thermal burns in and around Gulbarga city. Int J Med Pharm Sci. 
2013;3(11):11-6.

17. Gowri S, Naik VA, Powar R, Honnungar R, Mallapur MD. Epidemiology and Outcome of Burn Injuries. J Indian Acad Forensic Med. 2012;34(4):312-4.

18. Gupta R, Kumar V, Tripathi S. Profile of the fatal burn deaths from the varanasi region, India. J Clin Diag Res. 2012;6(4):608-11.

19. Sinha RC, Verma SK. A study of mortality in burns. A review of 1513 cases. Indian J Plast Surg. 1980;13:8-10.

20. Zopate PR, Tirpude BH, Murkey PN. Pattern of burn injury in the rural part of central India. Indian J Burns. 2011;19(1):42-8.

21. Bhardwaj SD, Sinha U. An epidemiological survey of burn injuries in rural area, Bhopal: A cross-sectional study. Indian J Burns. 2012;20(1):62-5. 101:104/03/09/1-653x.

22. Ghuliani KK, Tyagi NK, Narang R. An epidemiological study of burn injury. Indian J Public Health. 1988;32(1):24-30.

23. Ambade VN, Godbole HV. Study of burn deaths in Nagpur, Central India. Burns. 2006;32(7):902-8. doi:10.1016/j.burns.2006.03.001.

24. Gaffar UB, Yaseen M, Rizvi SJ. Medicolegal review of burns - A prospective study. Indian J Burns. 2007;15(1):18-23.

25. Khandare RR. Incidence of burn cases reported in tertiary care institute: A retrospective analysis. Int J Recent Trends Sci Technol.
2015;15(2):233-5.

26. Afify MM, Mahmoud NF, Azzim GAE, Desouky NE. Fatal burn injuries: A five year retrospective autopsy study in Cairo city, Egypt. Egypt J Forensic Sci. 2012;2(4):117-22. doi:10.1016/1.ejts.2012.08.002

27. Buchade D, Kukde H, Dere R, Savardekar R. Pattern of Burns Cases Brought to Morgue, Sion Hospital Mumbai: A two year study. J Indian Acad Forensic Med. 2011;33(4):311-2.

28. Mazumder A, Patowary AJ. A Study of Pattern of Burn Injury Cases. J Indian Acad Forensic Med. 2013;35(1):44-6.

\section{Author biography}

Swapan Debbarma, Senior Resident

Cite this article: Debbarma S. Pattern of flame burn injury in Dibrugarh district of Assam: An autopsy based analysis. Indian $J$ Forensic Community Med 2020;7(4):170-175. 